\title{
Identifying Learning Outcomes And The Use Of The Discussion Board In An Online Course
}

Kathleen Simione, (Email: kathleen.simione@quinnipiac.edu), Quinnipiac University Anne Rich, (Email: anne.rich@ quinnipiac.edu), Quinnipiac University

\begin{abstract}
With the popularity and resulting demand for online courses growing, many educators have developed at least a component of their courses, if not the entire course, online. These online courses, or components thereof, present many challenges to educators. Of the challenges faced, none is more important than learning. If we are not returning to the static model of learning but instead we are increasing the number of online courses then as educators, we must deliver online courses in which students learn through active participation. In developing online courses, one of the first challenges facing the instructor is to identify and communicate the learning outcomes of the course. Without identification of learning outcomes, instructors will not be able to assess learning. Once learning objectives are identified and assessments match these outcomes, faculty should find ways to create an active learning environment.
\end{abstract}

This paper describes the progression of an online introductory accounting course and how it evolved to improve the learning experience and create an active learning environment for students. Our experiences may provide useful examples that could be followed by others. The paper specifically describes the identification and communication of learning outcomes with related assessments and the use of the discussion board to foster an active learning environment.

\section{INTRODUCTION}

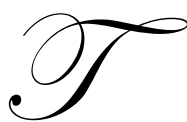

he demand for online courses has increased significantly in recent years. In 1997, the U.S. Department of Education found there were 1.3 million students enrolled in online for-credit courses. By 2001, that number had increased to 3 million (1). In a 2004 report (2) on selected schools, the growth in onsite students who took distance education courses doubled during the 2001-2003 period. In Connecticut, the Connecticut Distance Learning Corporation (CTCDC) (3) reported the number of online courses offered by Connecticut colleges in spring 1998 was less than 50, but by the Spring 2003, the number grew to over 500. Further, the number of Connecticut students taking online courses grew from "very few" in the Spring of 1998 to more than 5,000 in the Spring 2003.

This increased demand for online education has moved colleges and universities to begin or expand upon online course offerings. To do this, these same institutions must enlist interested and capable faculty. However, many faculty members are concerned that online courses may not provide the learning outcomes that traditional courses would. Delivery of quality education is important to all college educators who must be concerned with preparing students to meet the challenges of a constantly changing environment. This is particularly evident for business educators and more specifically, accounting professors. Since 1990, the Accounting Education Change Commissions (AECC) has encouraged accounting faculty to develop accounting curriculum that would prepare students to work in a challenging global economy. In their Position Statement \#1, the Commission identified the need for the professional accountant to be committed to continuous learning. According to the AECC, an education that creates a base on which life-long learning can build is required to prepare accountants to meet the demands of an evolving profession. Further, in Position Statement \#1, the AECC states that life-long learning is built on three components: skills, 
knowledge and professional orientation. It specifically listed general knowledge, intellectual skills, interpersonal skills, communication skills, business and accounting knowledge, accounting skills and personal capacities and attitudes among the capabilities needed by today's accounting graduates. With the ever-increasing online courses, could accounting courses be designed to meet these high expectations by the AECC? This paper will describe how the identification of learning objectives along with creative use of the discussion board will improve the delivery of accounting courses online and move in the direction mandated by the AECC to build the critical skills needed by accounting students.

\section{DEVELOPING THE COURSE}

Quinnipiac University is a medium-size private university located in Hamden, Connecticut. The administration introduced online courses in the summer of 2001 and agreed that online courses would only be delivered during the summer session. At that time some the faculty made use of Blackboard as part of their regular oncampus course. However, no one in the Department of Accounting was ready to develop an entire course online. The authors were asked to develop an undergraduate managerial accounting course for the summer of 2002.

It was obvious to us from the beginning that when teaching online, all course materials had to be made available to students on the software platform's course page (Blackboard). What was not obvious at the start was how those materials should be made available or used in the courses. In particular, how were we going to create an active learning environment as well as identify learning outcomes with appropriate assessments?

From 2002 to 2004, we revised the course as a result of our own learning curve regarding what appears to enhance the students' learning experience. The most discernible changes included identifying learning outcomes and use of the discussion boards.

\section{IDENTIFYING LEARNING OUTCOMES}

Initially, our course page identified some very general learning objectives that students were recommended to "pay particular attention to" when reading the chapters for that week. Based on the readings we then asked students to prepare solutions to a variety of assignments including questions, exercises, problems, quizzes and discussion board postings. There was no link for the students to understand how each assignment would help them to recognize a particular learning objective. To bridge this gap we now identify the learning outcomes for the week along with the specific activities that support that learning outcome (See Exhibit I). Now when a student prepares an exercise or posts to a discussion board they know specifically what learning outcome it is linked with. We feel that this will help focus student learning and, at a minimum, reduces frustration. It also helps faculty create assessments that follow logically from the material emphasized during the course.

\section{IMPORTANCE OF ACTIVE LEARNING}

Students who take online courses must meet the requirements of the course. In accounting courses, traditional requirements include activities like reading the text and solving exercises. However, many accounting professors have improved the classroom experience though active learning exercises. Active learning "connotes learning that is initiated by the learner, in the sense that it is carried out by the learner rather than simply "handed" or "transmitted" to him" (Hohmann, p. 130). A Stamford University Newsletter on Teaching defined active learning as "simply that - having students engage in some activity that forces them to think about and comment on the information presented." If we are entering into in an era that offers online education and moving away from the static model of learning then as educators, we must deliver online courses in which students learn through active participation. The question remains though, is it possible for an online introductory accounting course to create an active learning environment? 


\title{
EXHIBIT 1 - EVOLUTION OF PRESENTING LEARNING OBJECTIVES
}

\author{
Original Approach - Present all learning objectives in one section as follows: \\ Learning Outcomes for Week 1 \\ In this week, you will be able to: \\ 1. Explain purpose of each of the financial statements and the relationships among them. \\ 2. Prepare a set of simple financial statements. \\ 3. Identify and explain the primary assumptions made in preparing financial statements.
}

\author{
Revised Approach - Present activities associated with learning objectives within same section \\ Learning Outcomes for Week 1 \\ In this week, you will be able to: \\ 1. Explain purpose of each of the financial statements and the relationships among them. \\ Activities to support learning outcome \#1: \\ Read pages $\mathrm{xxx}-\mathrm{xxx}$ in the text \\ Do Exercise \# $\mathrm{xxx}$ \\ Participate in the Discussion Board \#xxx \\ 2. Prepare a set of simple financial statements. \\ Activities to support learning outcome \#2 \\ Read the financial statements of the XYZ company \\ Answer the questions in exercise \#xxx \\ 3. Identify and explain the primary assumptions made in preparing financial statements. \\ Activities to support learning outcome \#3 \\ Read pages $\mathrm{xxx}$ in the text \\ Write an essay identifying five primary assumptions underlying financial statements. Submit this assignment \\ through the link provided.
}

\section{USE OF THE DISCUSSION BOARD}

Active learning can be augmented in an online course through the use of the discussion board feature. Over the three years we have taught this course, we have made some changes. At the start, participation in the discussion boards was poor. If the students did participate, their postings reflected a lack of effort. As a result, we made the following changes:

1. Required participation and included points towards the final grade. (In other words, we assessed their participation.)

2. Set up discussion forums, so general questions were posted in one forum while specific discussion forums were created for specific cases and problems. (Added to the overall clarity)

3. Used the discussion board as a current events forum.

4. Monitored the discussion more frequently. (Jumped into the discussion just as if it was an on-campus class discussion. This allowed us to redirect the discussion by posting critical questions.)

5. Provided position feedback for students for thoughtful submissions.

Exhibit II provides an example of the discussions in a recent online accounting course. These changes made a discernible difference in the level of participation in the discussion boards. Students now frequently post more than the required amount of times as they respond to other students' postings as well as the instructor's. It also provided the instructor's with an opportunity to develop discussions as if they were in a traditional setting and as a result provide insight about the class. The instructor can replicate more of what is done in an on campus course to make the 
discussion more robust by actively participating in the discussion board. It is interesting how much is revealed about an individual through their responses in the discussion board. Our experience is consistent with the findings of Burton and Goldsmith who report "faculty need to be present in the threaded discussion" and "students appreciate wellthought-out discussion assignments" (5).

\section{EXHIBIT II - INSTRUCTORS' PARTICIPATION IN THE DISCUSSION BOARD}

\section{Student \#1:}

There is no real easier answer. I guess one of the beginning questions I would ask myself is, how much is the cost of my companies' reputation? Bad publicity can cost as much if not more in the long run. And being silent can be a sign of agreement. I have to remember that this is not the only client that I have and that I stand to loose more if the accusations against my company are true. ON the other hand, I need to ask is my company financially able to continue to fight. I'm already $957 \mathrm{k}$ in the hole. If I continue to fight I stand to be $2.5 \mathrm{~m}$ if not more down. One thing I would look to do is tell my legal team that they will not receive any monies unless we win. Not having all the information needed, I think I would look to settle and concentrate on my other clients.

\section{Student \#2:}

In this particular case I would settle out of court. The company's reputation has been already damaged by filing bankruptcy, and the fact that you have been accused of not warning the stockholders of the company's financial status. It seems to me, that if you had in fact warned the stockholders of the company's financial status that this would be easily proved in court with financial records, Board minutes and the correspondence that went out to the stockholders warning them of a financial demise. If in fact these precautions had been taken it would not take 957,000, and an additional 800,000 to prove this case. As Frank pointed out, you are in the hole by 2.5 million with no guarantee of restoring your reputation or business.

\section{Instructor Involvement:}

Student \#1 and student \#2 make some good points. Companies are always concerned about the costs and benefits of their decisions. Do other students in the class agree with student \#1 and \#2? Does anyone support going further with the lawsuit no matter what?

\section{Student \#3:}

I think it is important to save the company's reputation and go to court. In the long-run, the company's good reputation will be the payback.

Instructor Involvement:

Student \#3 presents a good reason for going to court. Are there any other alternatives that management has not yet considered?

\section{Student \#4:}

Considering I have spent $\$ 957,000$ in costs thus far, to then pay an extra $\$ 800,000$ in legal fees would end up being more money than if I just chose to settle. Therefore I would only be paying a total of $\$ 1,707,000$ rather than $\$ 1,757,000$. Considering the fact it is only another $\$ 50.00$ to prove my innocence, I believe the better choice would be to settle out of court and give more attention to my existing customers due to the damage this acquisition will have on my company's reputation. Trying to restore damaged reputations many times requires more attention than money which will benefit the shareholders in the end, which in turn helps the company to strive towards its goals.

\section{CONCLUSION}

There are now books and websites dedicated to sharing experiences on how to improve online courses. Identifying learning outcomes and matching activities to these outcomes is a good start. Using the discussion board where the faculty member actively participates will keep students interested. Just as faculty would work towards continuous improvements with their on-campus courses, we expect to continually make efforts to improve upon course delivery so that we can provide a better teaching and learning environment to our accounting students. 


\section{FOOTNOTES}

(1) Time Flies: Capturing the extra workload costs of the internet, by Joan Greenbaum, page 17, AFT On Campus, November 2004, Vol. 24, No. 3.

(2) Second Report to Congress on the Distance Education Demonstration Program, U.S. Department of Education, October 2004, p. 5.

(3) Connecticut Distance Learning Corporation website, research section 11/10/2004 http:www.ctcle.org/evaluation/factbook.html

(4) Hohmann, Mary, Banet, Bernard, and Weikart, David, Young Children in Action: A Manual for Preschool Educators, The High/Scope Press, 1979, Ypsilanti, Michigan, p. 130 - quoted from Piaget in Carmichael's Manual of Child Psychology (third edition volume 1, edited by Paul H. Mussen, Chapter 9, Piaget's Theory, published by John Wiley \& Sons, 1970.

(5) Students' Experience in Online Courses: A study Using Asynchronous Online Focus Groups, by Laura Burton and Diane Goldsmith, Connecticut Distance Learning Consortium, July 2002 found at www.ctdlc.org

\section{NOTES}


NOTES 